\title{
Performance and style in the work of Olgyay and Olgyay
}

\author{
David Leatherbarrow and Richard Wesley
}

The sun control device has to be on the outside of the building, an element of the facade, an element of architecture. And because this device is so important a part of our open architecture, it may develop into as characteristic a form as the Doric column. ${ }^{1}$

\section{Background: A House Reversed}

Victor Olgyay (1910-1970), a Hungarian architect who came to the United States in 1947 with his twin brother and collaborator, Aladár (1910-1963), is best known today as the author of Design with Climate: Bioclimatic Approach to Architectural Regionalism (1963), an important book often referenced in the environmental building design field [1]. As leaders in research in bioclimatic architecture from the early 1950 s to the late 1960 s, the Olgyay brothers could be considered the 'fathers' of contemporary environmental building design. Their research and publications laid the foundation for much of the building simulation software in use today. Other than the difference between working on graph paper and using computer-generated graphics, there is little difference between Autodesk's Ecotect Analysis (simulation and building energy analysis software) and the Olgyays' techniques for the analysis of environmental factors and graphical representation of climate. The manner in which the Olgyays established connections between building design and the science of climate laid the foundation for the development of environmental simulation, one of contemporary architecture's leading methods of form generation. Victor Olgyay's teaching, however, represents another kind of thinking, a broader concern for architecture, beyond energy performance. 'The primary task of architecture,' Olgyay announced to his students, 'is to act in man's favour; to interpose itself between man and his natural surroundings in order to remove the environmental load from his shoulders. The fundamental task of architecture is thus to lighten the very stress of life, to maximise man's energies and permit him to focus on spiritual tasks and aims.' ${ }^{2}$

Prior to his role as a teacher in the United States, Victor practised architecture in Hungary in collaboration with Aladár. Together with Farkas Molnár (1897-1945) and József Fischer (1901-1995), the twins were members of Hungary's architectural avant-garde. Called 'functionalist architecture' at the time, the works of the Hungarian group represent one of several regional branches of European Modernism. ${ }^{3}$ The ideas that guided the Hungarian approach were set out in the periodical Tér és Forma (Space and Form), a journal much like other avant-garde publications in France, Germany and Holland. The influence of Bauhaus teaching is evident in the work, particularly Molnár's, who was educated there. The impact of De Stijl, known in Budapest through the graphic designs of Vilmos Huszár, is obvious as well. The Hungarian Modernists were also active in the early meetings of the International Congresses of Modern Architecture (CIAM). A CIAM-Ost meeting was held in Budapest in 1937, but by 1938 Molnár recommended that the Hungarian contingent disband because of what he saw as CIAM's failure to achieve real results in the social sphere. That was the same year that the Olgyay brothers opened their professional office in Budapest. They had just returned from four years of study and travel

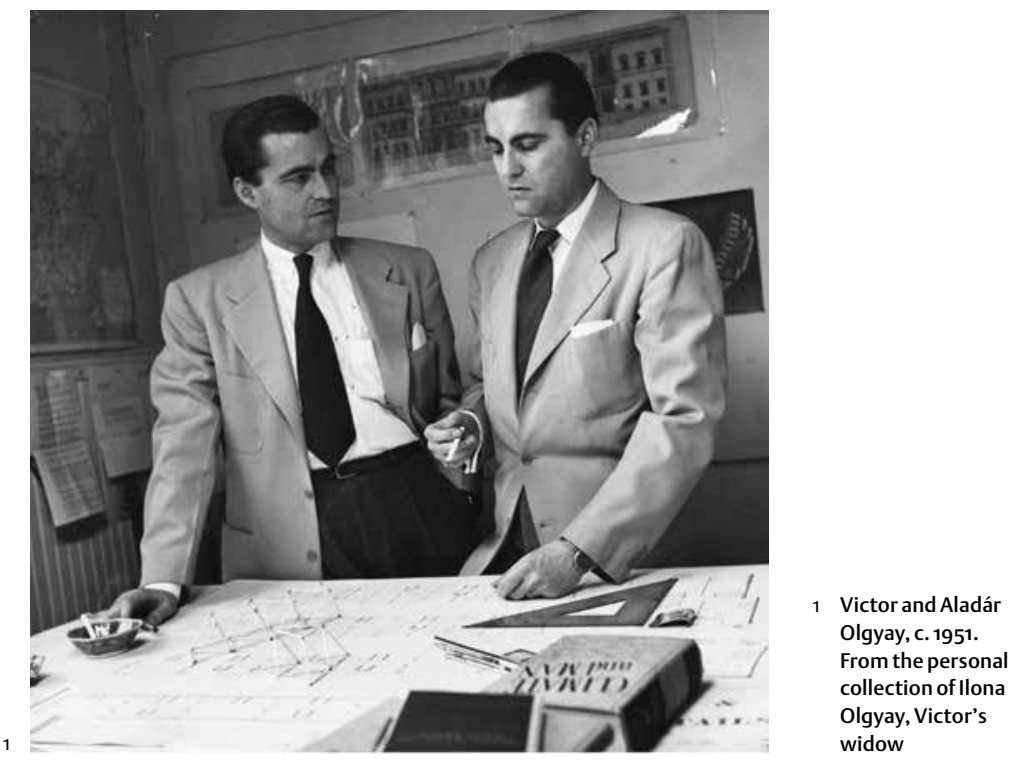


including a Prix de Rome (1934-35), followed by visits to Paris, where they met Le Corbusier; London, where they met the Hungarian-born Modernist Marcel Breuer; and New York, as Kendal Fellows at Columbia University (1936-37).

Yet, still another dimension of modern culture played a role in the Olgyays' understanding of 'spiritual tasks and aims': modern painting. Their father, Viktor Olgyay (1870-1929), was a prominent early-twentieth century Hungarian artist, famous for his etchings and landscape paintings, but also well-known as a teacher at the Academy of Fine Arts in Budapest, one of the founders of the Hungarian Watercolor and Pastel
Painters Society, and president of the Hungarian Graphic Designers Association. He was dedicated to plein-air methods and had regular contacts with European painters who followed this path, partly as a result of his involvements with members of the several artist colonies around Budapest. He frequently depicted forest scenes, particularly in winter, when contrasts were especially strong and the shadows of trees striking in their patterns and rhythms. ${ }^{4}$ His influence was felt among his students and fellow artists, but also among his sons, whom he frequently took on his artistic trips into the countryside. 'Much of their early education took place in their father's studio,' wrote Peter

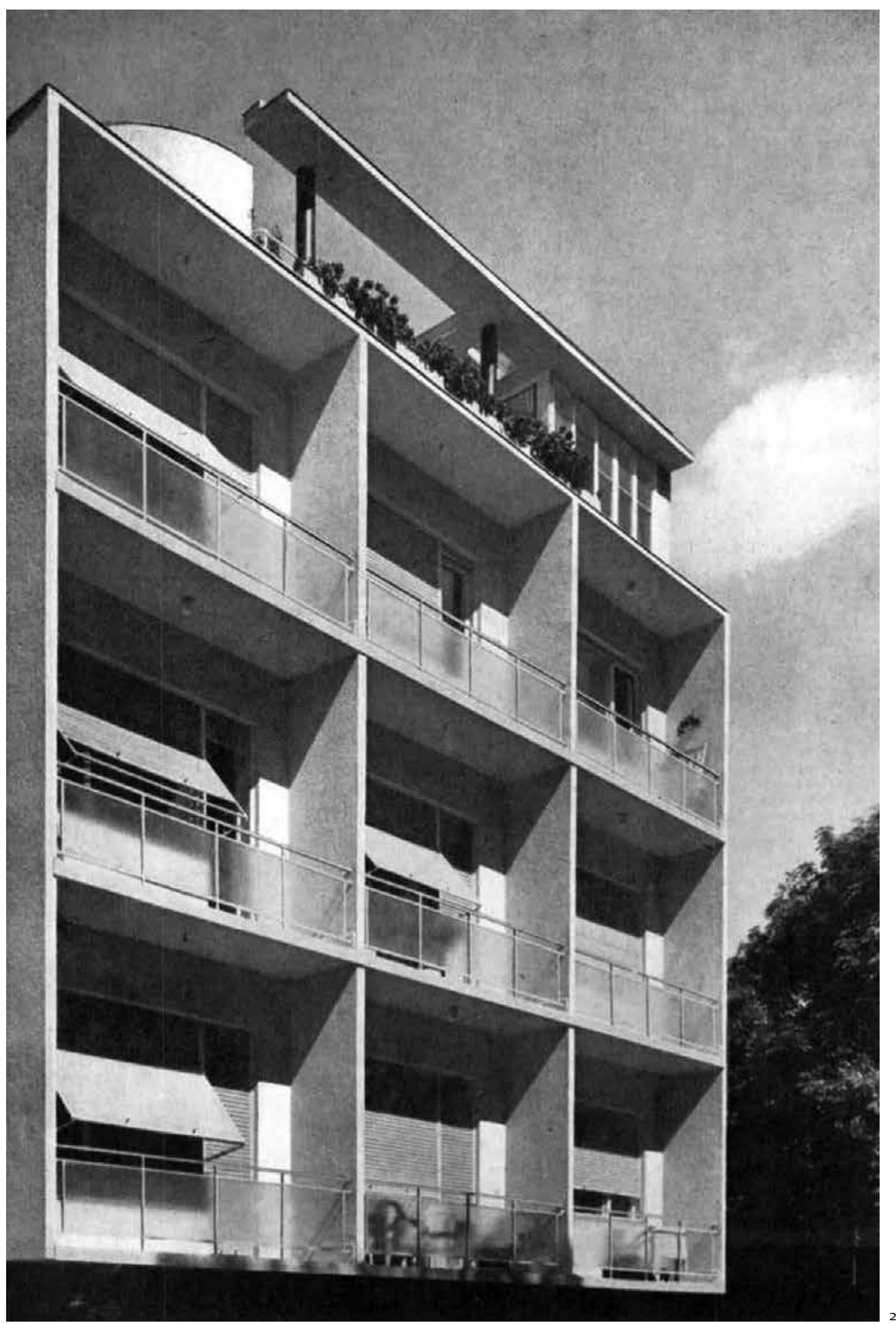


Blake, 'and it was not entirely unexpected that he should ask them to follow in his footsteps. The temper of the times, however, was enthusiastically technocratic [...] the Bauhaus was dedicated to the education of a new type of specialist - the industrial artist. The Olgyays were not immune to this infectious new spirit. ${ }^{5}$ Against their father's wishes, the twins enrolled in the Royal Hungarian Polytechnic, earning diplomas in 1934.

But while the prime emphasis in their training thus became scientific and technological, they continuedon the side - to pursue various activities closer to the spirit of their early upbringing. Among these activities was the design of stage sets for the Royal Hungarian Opera house, mural painting, and so forth ${ }^{6}$

This background and cultural context set the stage for a productive architectural practice in Hungary in the late 1930 and early 1940s. The Olgyays' built work during this time included apartment houses, hotels, housing projects, exhibition buildings, and factories. One project from this period can be taken as indicative of their approach, an apartment building constructed in 1939 in the centre of Budapest [2]. 'A House Reversed' was the name given to this building in The Work of Architects Olgyay + Olgyay, published in Hungary in 1946 and 'printed both in Hungarian and English as part of a strongly pro-Western tendency in post-war Hungarian thought. ${ }^{7}$ Why 'reversed?' Because the main living spaces faced the garden, not the street, reversing the typical orientation of the city's buildings. The re-orientation was not the only divergence from typical local building solutions. Unlike most of the other buildings in its immediate context, this building was modern. Giancarlo Palanti described the house as an alternative to the 'fashionable front architecture', and the 'eloquence of extravagant palaces' that stood nearby and had become the norm. The Olgyays' building was by contrast 'practical', 'rational' and 'healthier and brighter'. ${ }^{8} \mathrm{~A}$ brief explanation offered by the Olgyays themselves (much later, in 1957) suggests that functionality was also important. ${ }^{9}$ Because the house faced southeast, protection was needed against the sun; more specifically, protection from the overheating that would result from the exposure of large expanses of glazing. Their solution, and the building's most prominent element, was a shading device attached to the exterior of the wall that extended the geometry of its floor levels and apartment divisions with thin slabs and fins approximately one metre deep. The general aim, Palanti observed, was 'perfecting the use of the flats for the inhabitants. By the use of balconies and large windows along the whole length of the building, every flat can enjoy the garden air. ${ }^{10}$

Does this mean the building's design was based on programmatic and environmental functionalism? In part, yes, but that is not all; for the Olgyays also saw the building as revealing new forms of expression: 'a pulsating lively rhythm born from the architecture itself', a 'constructive rhythm', in which 'new expressions' made evident the 'creative power of architecture. ${ }^{11}$ The stylistic aspects of the facade place it among buildings in the heroic period of Modernism: unadorned surfaces, prismatic rectangular volumes, white walls, a roof terrace, and an external sun screen. Apropos style in architecture, Joseph Rykwert suggests three characteristics are decisive: that its forms are visibly evident, that those forms can be catalogued, and that they can be 'summed up, imitated, and even applied. ${ }^{12}$ The description of 'A House Reversed' as expressive and rhythmic points in the direction of the visibly evident stops short of explicitly identifying elements of architectural form that could be catalogued or imitated. Yet, these forms are obvious. Chief among them is the 'egg-crate' sun screen. Designed to provide some shade, along with adjustable external shades, the nine-bay sun screen is the facade's most prominent figure, legible in its simple regularity and relative autonomy with respect to the body of the building. Its non-singularity or typicality within the modern tradition is also plain when you look at precedents from Germany, Holland, France and Italy. That examples of sun screens, such as this one, could be collected, catalogued, summed up, imitated, and even applied, becomes clear when we turn to the books published by the Olgyays following their emigration to the United States in 1947.

\section{Environmentalisation of architecture}

The Olgyay brothers published three books on bioclimatic architecture: Application of Climatic Data to House Design (1954); Solar Control and Shading Devices (1957); and in 1963, by Victor only, the well-known Design with Climate: Bioclimatic Approach to Architectural Regionalism. Although the three books share some text and illustrations, there are significant differences between them relative to the trajectory of environmental building design. The Olgyays' little-known first book, Application of Climatic Data to House Design, was a report prepared for the US Housing and Home Finance Agency. The title and the funding agency suggest an approach to house design based exclusively on environmental factors. Yet, the images on the cover suggest otherwise [3]. The caption reads:

The cover of this report shows T. F. Blondell's [sic] subjective evaluation of a Tuscan overhang, which he compares with a profile of a youth in his Cours d'Architecture (1750). The present day multistory wall with its pattern of light and shade, and proportion, likewise serves well to compare the old with the new. ${ }^{13}$

The 'present day multistory building' on the cover was a photograph of the sun screen on the Ministry of Education (1937-43) in Rio de Janeiro by Oscar Niemeyer, Le Corbusier, and others. There is a third image on the cover, not mentioned in the caption: a shading protractor. A technical graphic device, long since replaced by computer simulation, the shading protractor consists of segmental lines on the top half used to plot lines parallel and normal to an observed wall, while the bearing and altitude lines on the bottom half of the protractor are used to plot the mask of any shading device. That the 


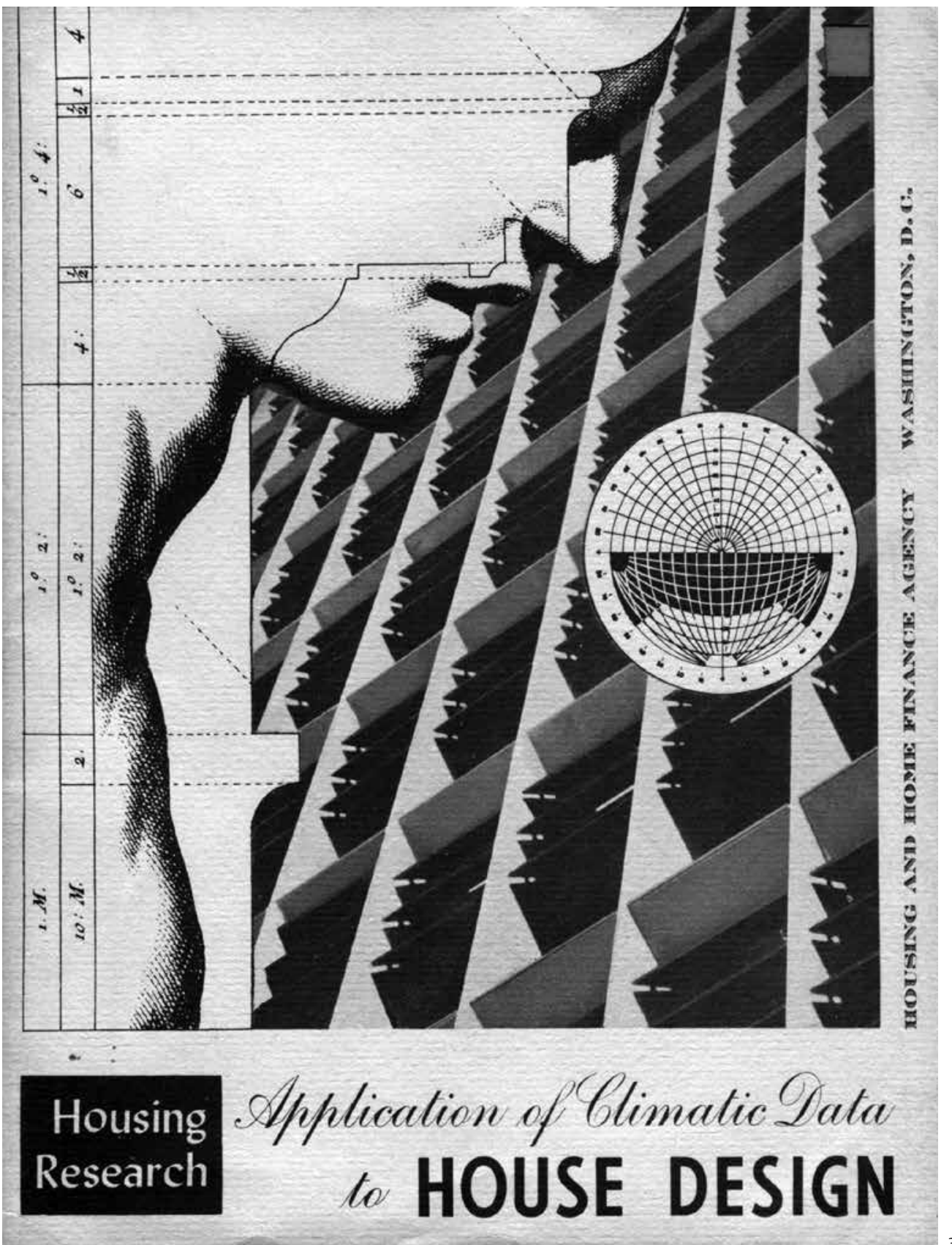

Olgyays chose a Classical drawing of the profile of a human face and positioned it so that it appears to be gazing at the sun screen of a modern facade through the lens of a shading protractor represents a provocative proposition: building elements designed in precise reaction to environmental factors could become the 'visibly evident' elements of a new architectural style equivalent to the Classical. ${ }^{14}$ Such a proposition moves far beyond programmatic and environmental functionalism. It incorporates and transcends the more narrow and exclusive approach to architecture promoted through the techniques and theories of those contemporary environmental building designers who only see the Olgyays' approach as the first step in an inevitable environmentalisation of architecture, i.e. the analysis, simulation and generation of architecture on the basis of environmental factors - often to the exclusion of other considerations. ${ }^{15}$
The process for the creation of an environmentalised architecture depicted by the Olgyays follows from their understanding of an environmentalised human body. In this process, they understood that architects play an essential role in the production of shelter, which is necessary to control the interior environment and bring it as close as possible to the balance point of metabolism, or the human comfort zone. The process, as described by the Olgyays in a diagram published in all three of their books on bioclimatic architecture, consists of two steps [4]. First (top): conceive of an ideal mode of reaction through an analysis of 'all of the environmental elements' based upon an understanding of man as a biological organism reacting to environmental elements in order to achieve and maintain thermal comfort, that is, the balance point of metabolism. This idealised mode of reaction is depicted here as a hovering, dome-like enclosure surrounding 


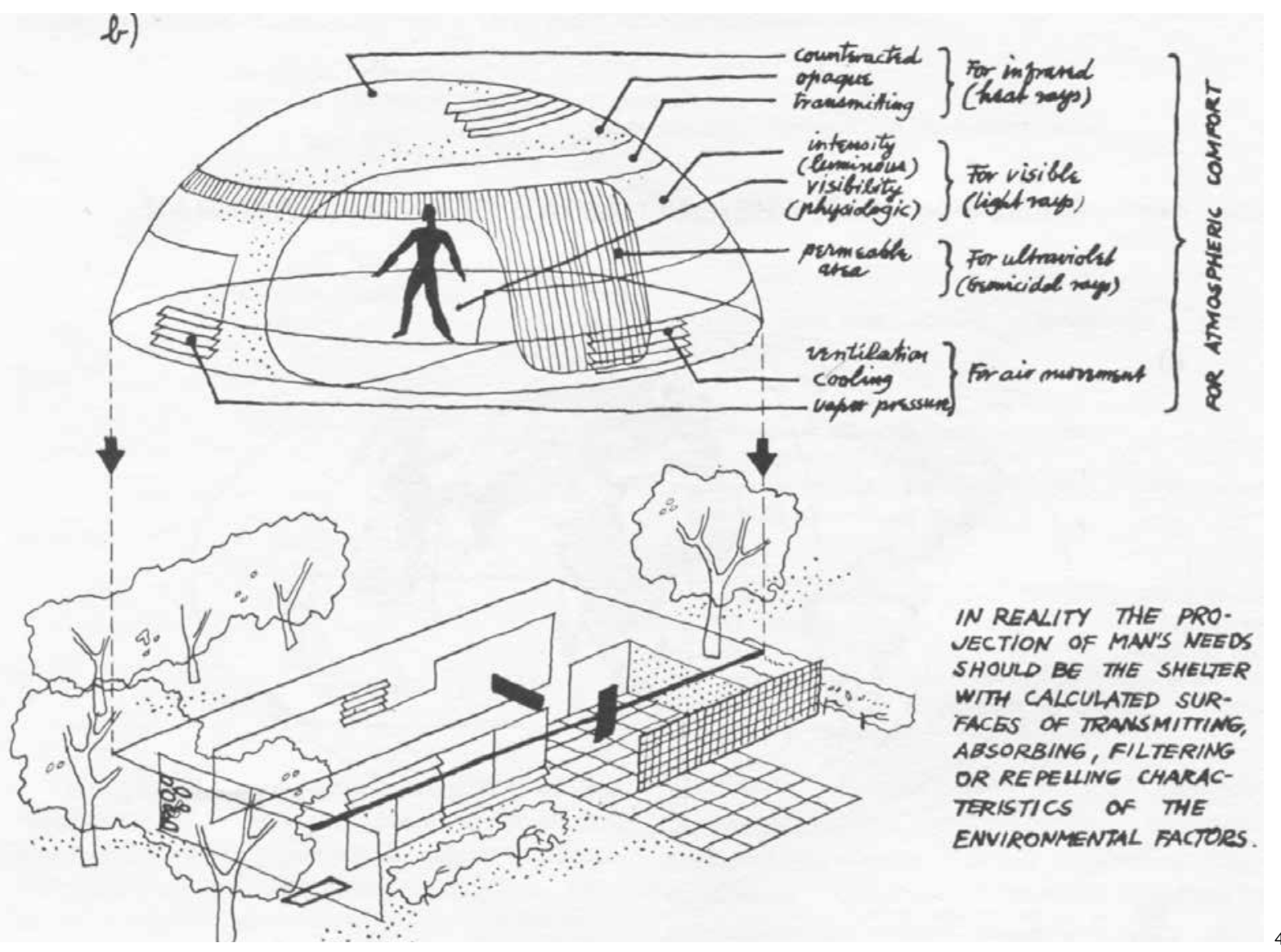

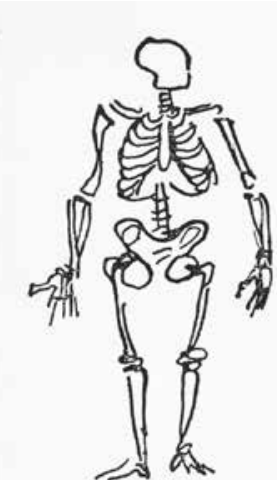
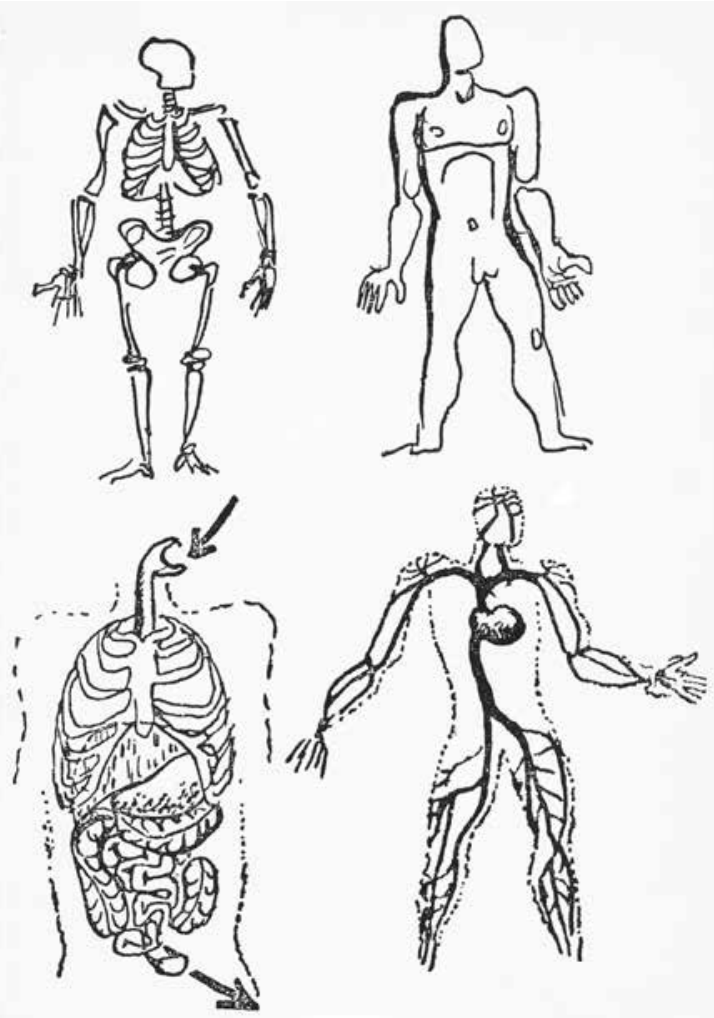

4 Environmental Building Design Process. From Application of Climatic Data to House Design (Washington DC: US Housing and Home Finance Agency, 1954), p. 10 the human body. Second (bottom): translate these idealised reactions into architectural form. The hovering, idealised object has landed and been transformed into an orthogonal, free-plan house Barcelona Pavilion-like in its composition - roofless, and surrounded by trees. The text at the bottom right of the image is a telling description of the environmentalisation of architecture:

[...] in reality the projection of man's needs should be the shelter with calculated surfaces of transmitting, absorbing, filtering or repelling characteristics of the environmental factors. ${ }^{16}$

This notion of a 'shelter with calculated surfaces' is perhaps the most accurate and earliest indication of the environmentalisation of modern architecture, a process that continued for decades, and has been substantially fortified today with advanced computer simulation.

The first premise of a bioclimatic approach to architectural design is that the human body is architecture's 'physiological measure' ${ }^{17}$ The idea that design thinking begins with study of the human body is not, of course, exclusive to the bioclimatic or environmentalist approach; it is a commonplace of architectural theory, central in writings from Vitruvius to Le Corbusier. The key issue is how the body is understood. The particularity of the Olgyays' approach can be seen when two depictions of the body are compared: theirs and one by Le Corbusier. The inner workings of the body interested Le Corbusier no less than the Olgyays. His drawing shows a series of specialised systems - skeletal, digestive and circulatory - hidden beneath a visible skin [5]. The surface of the skin is 
critical because it unifies the systems into a single mass - the body's familiar form. Le Corbusier's caption supports his appreciation of a body whose continuous surface allows it a particular interaction with light:

Final harmony crowning a complex work, an arrangement of perfection. The intelligent, correct and magnificent play of forms in light. ${ }^{18}$

In Towards an Architecture (1923), he used a similar phrase to describe architecture as "the masterful, correct, and magnificent play of volumes brought together in light., ${ }^{19}$ The Olgyay brothers, by contrast, show the body to be a dense circulation system used for heating and cooling, the task of which is to maintain the 'operative temperature' or balance point of metabolism [6]. ${ }^{20}$ There is, however, no skin in the Olgyays' drawing; the body's profile, such as it exists, is the outer edge of masses of veins and capillaries. The absence of an envelope in the drawing appears to more easily connect the organism with ambient conditions, but at a substantial cost to the visibility of the body's form. Vectors extending downward join it to the Main Climatic Elements - air temperature, radiation, air movement and relative humidity - while those that extend upward pinpoint its reactions - evaporation, conduction, convection and radiation. In the centre of the body, which the Olgyays called the navel of convergence, are found the 'Indices of Comfort,' represented in a mathematical formula. Developed by Winslow, Herrington, and Gagge in 1941, the formula is a mathematical model of the complex relationship of climatic elements expressed in a calorimetric scale, where $\mathrm{T}$ is the Operative Temperature (balance point of metabolism); $\mathrm{t}=$ mean skin temperature; $\mathrm{M}=$ metabolic rate; $\mathrm{E}^{\mathrm{s}}=$ evaporative rate; and $S=$ body heat loss or gain. ${ }^{21}$ Here is a depiction of an environmentalised human body, the organism as a 'machine for thermal comfort', an instrument of reaction to environmental factors. Thinking analogically: when the body is viewed as a machine for thermal comfort the building will be seen as a device that maintains 'operative temperature'. Instruments designed for this purpose were explained and catalogued in the Olgyays' Solar Control and Shading Devices. ${ }^{22}$

Their text begins not with analysis and data but rather with quotations from Le Corbusier, the modern architect whom they thought was acutely sensitive to the 'vulnerability' of modern buildings to the problems of thermal comfort. They cited him saying:

It becomes necessary [in the modern way of building] to stop up the windows, to 'diaphragm' the glass pane. What aids are available to accomplish this end? ${ }^{23}$

While this question may have been challenging in Modernism's early years, decades of innovation in Europe and North and South America provided numerous answers in the post-war years. Le Corbusier's architecture in particular - even the buildings before his so-called organic or regionalist turn - provided the Olgyays with a catalogue of elements that could bring the body into equilibrium with the environment. First there were the different fenestration patterns Le Corbusier had developed in his early houses and villas: Cook, Savoye and Garches. Next came the different treatments of the glazing, alternating bands of transparent and translucent windows, as in the Swiss Pavilion and the Clarté Apartments. A key development in this history is the separation of structure from shading devices, as in the Villa at Carthage. After this followed new combinations of deep spaces and shutters, as in the Barcelona housing project. Subsequently, facades were differentiated according to orientation. The amount of glazing was varied from side to side, as was the depth of the sun-breakers. Vertical or horizontal elements were deployed individually or in combination. The best example of this treatment is the Maison Curutchet. The Olgyays viewed the Ministry of Education in Rio as the summation of all of Le Corbusier's research. We have already seen that this is the modern building they juxtaposed with Blondel's profile of the Classical cornice. In Le Corbusier's designs for Algeria they felt that, 'the arrangement of solar control and construction had been "organically coupled", for there the brise-soleil (sun breaker) was united with a system of construction, 'moulded into unity'. ${ }^{24}$ They did not note, however, that this coupling, which made the sun-breaker an extension of the building's load-bearing structure - of similar mass and non-adjustable - created its own problems: heat absorption and transfer, and inflexibility. The shading elements the Olgyays described - not sun-breakers, but masking devices - avoided these problems, without sacrificing the freedom of expression Le Corbusier's solutions also revealed.

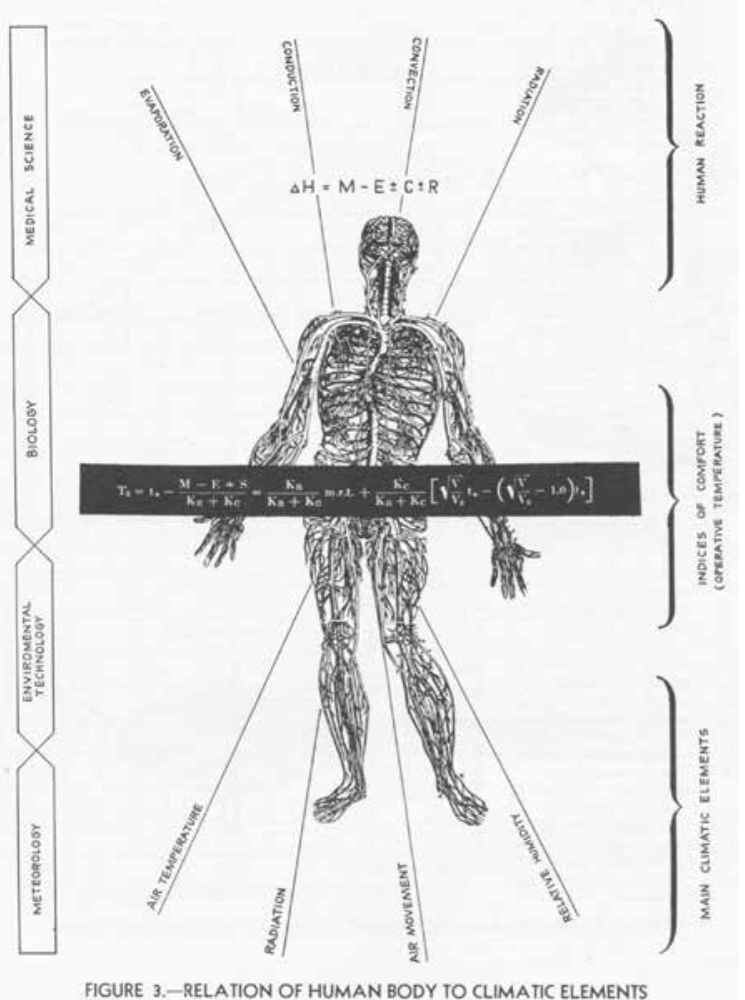




\section{Shading devices: types and patterns}

What did the Olgyays understand as a 'shading device?' Essentially, it was a shadow caster. In the human body its equivalents would be eyelashes and eyebrows. A hand raised to the forehead serves the same purpose: reducing sun glare, shading the face and therefore cooling. In clothing, a comparable element is the brim or visor of a hat. When the term 'shading device' was introduced in Solar Control and Shading Devices it was described as an 'obstruction,' its task was to 'interfere' or 'interrupt' solar radiation. ${ }^{25}$ In Design with Climate a synonym for shading device was 'obstruction pattern' ${ }^{26}$ Clouds in the sky serve a similar function; they interrupt sunshine and obstruct parts of the total view. Below the vault of the sky, on the street, buildings and sometimes trees are equivalent shadow casters, allowing one's eyes, the 'point of observation', to receive solar rays from 'only those parts of the sky vault where the sun's path is visible.' The other consequence of 'interference' - the most important one for the Olgyays - is the projection of a shadow on surfaces the sun's light would have reached. The Olgyays defined the configuration of these shadows as 'the shading mask'. ${ }^{27}$ The distinction is significant, for many devices can accomplish the shadow-casting outlined by the mask:

Since various devices might have the same mask and therefore the same shading characteristic [...] To choose between them is the designer's task. Here the domain of creative design starts. ${ }^{28}$

Nature provides a model, for its 'infinite variations' show how a 'multitude of organisms - subordinated to a complicated hierarchy of rules - produces abundant creations. ${ }^{29}$ Shading masks or diagrams are thus both descriptive and projective, they plot the shadow pattern a device will produce in a given location and they propose a range of solutions for the device itself. Yet, the graphic mask never determines a solution because 'there will be many technically correct solutions for each situation. ${ }^{30}$

Accordingly, the shading devices installed onto a building both solve environmental problems of comfort and represent a selection made from many possible impressions. Once again, reference to the human body will be helpful, as will the parallels between the shading device and the facial mask. Anthropologically, masks both conceal and express. What do they conceal? In a word, an identity; which is why criminals wear them and why children find some of them frightening. In all cases, what the body is by nature is hidden by the mask. Signs of age, gender, colour and individuality are veiled so that a person can become someone else, at least for a while. Concealment, then, is not the only aim of masking; the mask also transforms the person into a persona, 'larger than life', capable of expressing a strong impression. When a person wears a mask the 'limitations' felt from birth are temporarily overcome. For this to occur, negation is necessary (like the 'obstruction' caused by the shading device). Two final points are important: masks intend communication and they fix a certain type of expression. No one would wear a mask that was not recognisable, and because they are fully frontal, masks concentrate the gaze and express and stabilise an impression, a character, or idea.

Do shading devices on buildings perform similarly? By negating what exists according to nature (or by necessity) can they both conceal and reveal? The answer for the Olgyays was clear: solving problems of glare and solar gain was necessary in the type of construction that allowed window walls, but was not sufficient - 'the practical and direct

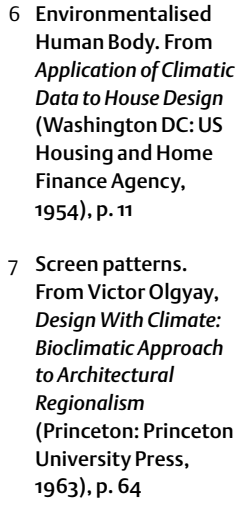

6 Environmentalised Application of Climatic Data to House Design Washington DC:US . Finance Agency,

Screen patterns. From Victor Olgyay, Design With Climate:
Bioclimatic Approach to Architectural Regionalism University Press, 1963), p. 64

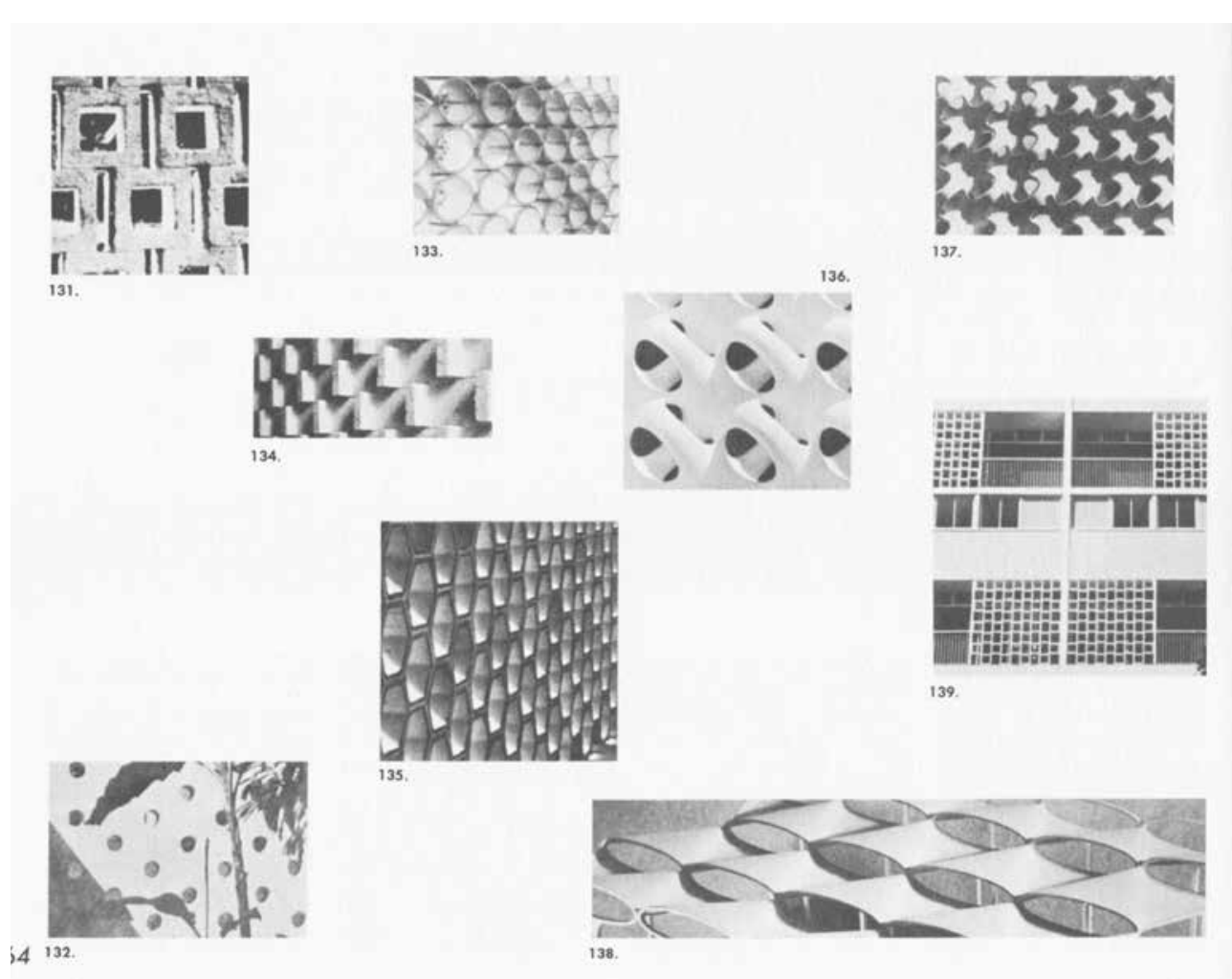



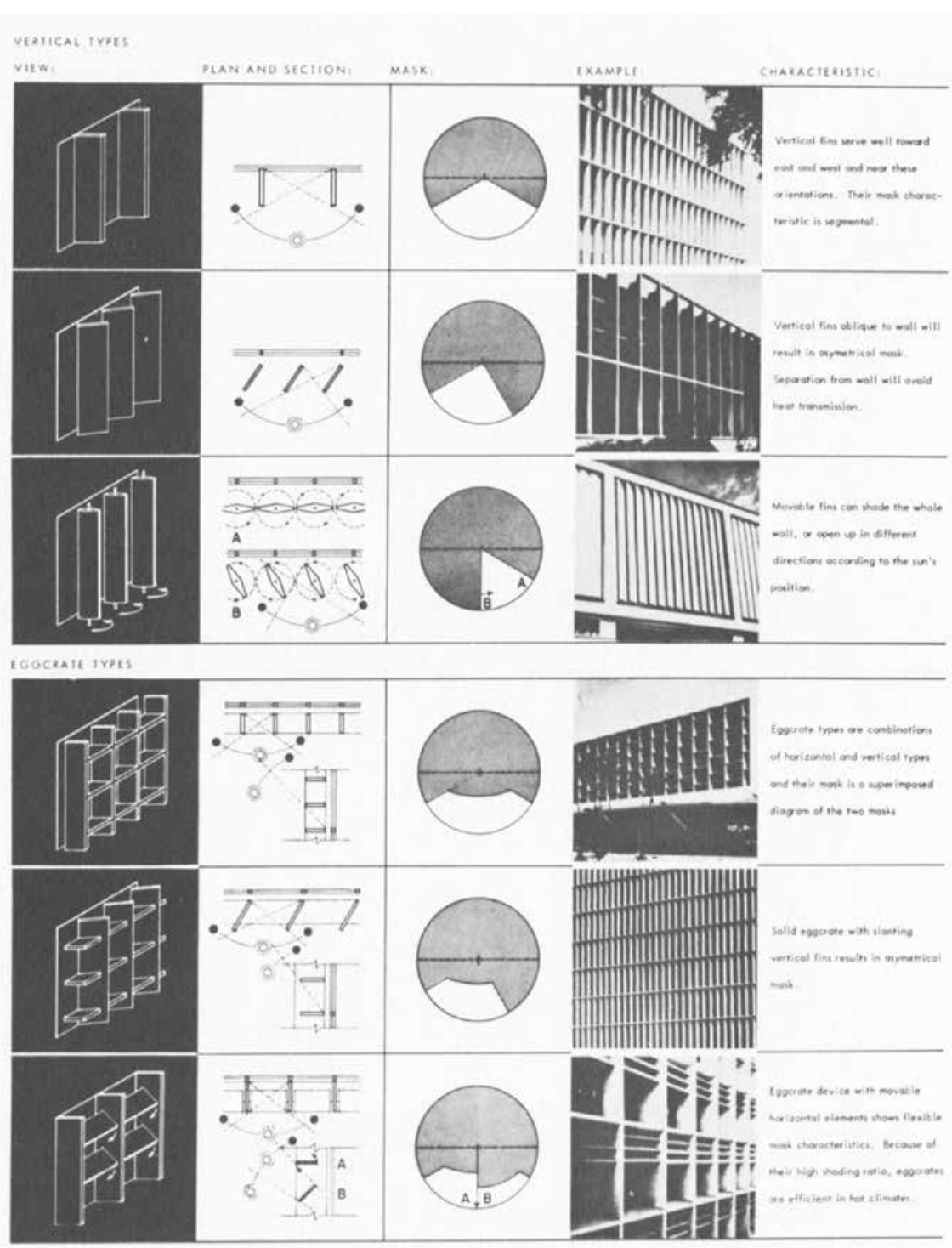

expression of rational necessities no longer gives complete satisfaction'. Even though 'the battle for functional solutions had been won' in the heroic period of Modernism, the fight on behalf of the shading device had to continue into Modernism's second critical period, for there was still the struggle for 'the lyrical heart and its emotional needs. ${ }^{31} \mathrm{~A}$ formalist approach was the farthest thing from their minds, for it was only after 'the more abstract ground work' had been completed that the 'luxury of emotional variation [could] flourish'. Shading devices are expressive because they 'invite a rich play of light and shadow', and to their 'plastic appearance they add rhythm, light, color, and texture'. 'Patterns might be geometrical or use the fluid play of the claire-obscure [sic] of the light. ${ }^{32}$

The play of shadows they had in mind can be seen in a series of carefully cropped photographs published in both their Solar Control and Shading Devices book and Design with Climate [7]. Trimmed and sized as they are, these photographs deprive the devices of specific relationships to the climates they modify and the interiors they protect. They are, the Olgyays observe, 'independent of direct scale, and leave only geometrical relationships to the masters'. But again, this proposal for composition and expression should not suggest formalism or capricious play. All the motifs were understood to be 'subordinate to the sun, whose strength and angles, according to orientation and location, prescribe the regional patterns. ${ }^{33}$

Because typical problems lead to typical solutions, shading devices can be categorised or catalogued typologically [8]. There are three types: horizontal, vertical and egg-crate; the third combines the first two. As with masks in general, these types can be embodied physically and represented graphically. For horizontal overhangs the typical graphic characteristics of the shading diagram are segmental lines. The shading masks created by vertical louvres appear on the drawings as radial lines. Insofar as the egg-crate types combine the attributes of horizontal and vertical devices, their 'mask characteristics' are a combination of segmental and radial lines. The Olgyays broadened this last observation with a summary statement: 'it would be an endless task to show all types [...] many further combinations of shading devices are 
possible, resulting in combinative masks. ${ }^{34}$ Types such as these are schematic; more like ideas than facts, regulative principles rather than specific solutions. It was perhaps for this reason that the term 'vocabulary' was used interchangeably with type. Grammar might have been a better word, or syntax, for the shading masks schematise and structure solutions prior to their detailed articulation and concrete resolution. Nevertheless, the use of the term 'vocabulary' allowed the Olgyays to stress the expressive character of the shading device, once the diagram had been transformed into a specific solution.

One further categorisation is necessary: the elements that make up built masks can be fixed or movable in any of the three types. This was the case in 'A House Reversed' where the egg-crate was fixed while the awnings were adjustable. An important presupposition of this second tabulation is that the device is conceptually distinct from the rest of the building to which it is attached. This, too, appears in 'A House Reversed'. Movable elements not only enhanced performance, by allowing seasonal and daily adjustments, they also multiplied light and shadow. Two scales of elements and types of movement - of the sun and of the louvres - cast a potentially infinite number of shadows and patterns. Furthermore, even though they indicate responsiveness to environmental conditions, the elements, fixed or movable, were not precisely determined by the climate - many combinations were seen to be possible, creativity was not only allowed but required. Despite what is often said or assumed about the 'environmentalist' approach outlined by the Olgyays, their concern was no less artistic than functional:

[...] the elements shown are independent of direct scale [...] many materials only elaborate the surface, others invite a rich play of light and shadow or add to the spatial composition [...] to their plastic appearance they add visual ties or rhythm, light, color, and texture. ${ }^{35}$

Practicalities were important, but not more important than patterns.

\section{Conclusion}

No arguments are necessary to defend the statement that the work of the Olgyay brothers prefigured environmentalisation in architecture. The seeds of this movement can be found in their books and buildings; but that is not all that can be found there, nor is this legacy adequate to fully explain their work. In the Olgyays' work, the study of climate unfolds in the cultural arena. The design of shading devices intends solar control and formal expression. The shadows these elements produce create physical comfort and a play of light and dark. Yes, the body and buildings are seen as instruments capable of modulating temperature; but the 'interpositions' that perform in the latter sense also create expressive patterns. The Olgyays' use of data, calculations and analytical diagrams suggests a design method unconcerned with aesthetic issues; yet, when the book-cover images, cropped photographs, and references to history and experience are kept in mind, the inadequacy of a strictly environmentalist interpretation is obvious. Their architecture - built and unbuilt - belonged to a style that emerged in the cultural context of Hungarian Modernism. They did not, however, accept the modern inheritance uncritically; for they realised it needed correction and could be enriched, enhancing performance while developing expressive possibilities. Somewhat like a solar eclipse, the work of the Olgyays cast a shadow on international Modernism all the while being held in orbit by its gravitational pull. The shadow was not homogeneous, however; it consisted of levels of darkness. Surrounding a fully shaded inner region of environmental performance, we found a partially shaded outer region of patterns, combinative masks and style.

\section{Notes}

1. Peter Blake, ed., Marcel Breuer: Sun and Shadow: The Philosophy of an Architect (New York: Dodd, Mead \& Company, 1955), p. 117. Marcel Breuer was one of several Hungarians who remained in close contact with one another after emigrating to the United States. In addition to Victor and Aladár Olgyay there was György Kepes, for example. Breuer wrote the Introduction to the 1952 book, The Work of Architects Olgyay + Olgyay, cited below, and Kepes designed its cover. A preliminary version of this paper, 'Eclipsing Modernism: The Olgyay Brothers and the Environmentalization of Architecture', was presented in Architecture and Energy: Questions About Performance and Style, a conference held at the University of Pennsylvania on 27 January 2012.

2. Victor Olgyay, Bioclimatic Factors in Architecture, course syllabus, Princeton University, spring term, 1969-70, typescript, p. 1. Syllabus held in Victor Olgyay Drawings and Papers, 1952-1970, Arizona State University Library Collections, Tempe, Arizona.

3. Here, we agree with Jürgen Habermas's account of modern architecture as 'the first and only binding style ... to have shaped even everyday life, since the days of classicism .... It continued the line of tradition of Western rationalism and was powerful enough to create models, that is, to become classical itself and to establish a tradition that from the beginning transcended national boundaries.' Jürgen Habermas, 'Modern and Postmodern Architecture', in The New Conservatism: Cultural Criticism and the Historians' Debate (Cambridge: MIT Press, 1989), pp. $7^{-8}$.

4. 'Viktor Olgyay studied under William Unger in Vienna and under Theodore Alphonse in Paris. As he originally intended to devote himself entirely to the graphic arts, and only later took up oil-painting, his technical knowledge of etching is remarkable. He is pre-eminently a draughtsman, and though his plates are finely toned, the most notable thing about them is their sense of line. Some of his best works are contained in an album 
of ten plates entitled Winter, and other notable ones are The Oak, The Mill, and Way of Cypresses.' Anthony Tahi, 'Modern Etching and Engraving in Hungary', Modern Etching and Engraving (London: The Studio, 1902), p. 2.

5. Victor Olgyay and Aladár Olgyay, The Work of Architects Olgyay + Olgyay (New York: Reinhold, 1952), p. 8.

6. Ibid

7. Ibid. Comment by Peter Blake. The project was first published in an article written by Virgil Bierbauer, the editor of Tér és forma, 'Városmajor-utca 5o/a számú bérház', Tér és forma, vol. 14, no. 9, 1941, pp. 156-61.

8. The Work of Architects Olgyay + Olgyay, p. 16. An English translation of 'Una casa a rovescio', in Domus, 20:169 (January 1942), pp. 7-11, attributed by the Olgyays to Giancarlo Palanti.

9. Olgyay and Olgyay, Solar Control and Shading Devices (Princeton: Princeton University Press, 1957), p. 165.

10. The Work of Architects Olgyay + Olgyay, p. 16.

11. Ibid.

12. Joseph Rykwert, 'On the HighTech Style', in Heaven and Earth: An Anniversary Issue to Honor Karsten Harries, Wolkenkuckucksheim, vol. 12, no. 1 (August 2007), p. 3. Our italics.

13. Victor Olgyay and Aladár Olgyay, Application of Climatic Data to House Design (Washington DC: US Housing and Home Finance Agency, 1954). Jacques-François Blondel's first initial and surname are incorrect in the caption.

14. The idea that a technical solution, such as the "brisesoleil', could have expressive purposes was discussed by Alan Colquhoun in 'The Significance of Le Corbusier', in Modernity and the Classical Tradition (Cambridge, MA: MIT Press, 1989), p. 187, where he wrote: 'But the brise-soleil was more than a technical device; it introduced a new architectural element in the form of a thick, permeable wall, whose depth and subdivisions gave the facade the modeling and aedicular expression that has been lost with the suppression of the window and the pilaster.' The epigraph by Marcel Breuer we have used to open this study expresses the same point.

15. The concept of 'environmentalisation' was defined by Frederick H. Buttel in 'Environmentalization: Origins, Processes, and Implications for Rural Change', in Rural Sociology 57:1 (1992), p. 2, as 'the concrete expression of the broad force of greening in institutional practices'. Our use of the term refers to the adoption of an exclusive discourse in architecture based on environmental factors and the generation of architectural form using environmental simulation.

16. Application of Climatic Data to House Design, p. 10

17. The title of Olgyays' Report Number 1 in Application of Climatic Data to House Design is 'Man as a Physiological Measure in Architecture'.

18. Le Corbusier and François de Pierrefeu, The Home of Man, trans. from La Maison des Hommes, Clive Entwistle and Gordon Holt (London: The Architectural Press, 1948), p. 124.

19. Le Corbusier, Towards an Architecture, trans. from Vers une architecture, John Goodman (Los Angeles: Getty Publications, 2007), p. 109.

20. Application of Climatic Data to House Design, p. 3.

21. C. E. A. Winslow and L. P. Herrington, Temperature and Human Life (Princeton: Princeton University Press, 1949).

22. Olgyay and Olgyay, Solar Control and Shading Devices (Princeton: Princeton University Press, 1957).

23. Ibid., p. 10.

24. Ibid., p. 11.

25. Ibid., p. 7 and pp. $44^{-} 5$.

26. Victor Olgyay, Design with Climate: Bioclimatic Approach to Architectural Regionalism, (Princeton: Princeton University Press, 1963), p. 78.

27. Solar Control and Shading Devices, p. 45 .

28.Ibid., p. 49

29. Ibid., p. 13.

30. Design With Climate, p. 13 and p. 83.

31. Solar Control and Shading Devices, p. 12.

32. Ibid., p. 15.

33. Ibid., p. 15.

34. Ibid., pp. 48-9.

35. Ibid., p. 15.

\section{Acknowledgements}

The authors gratefully acknowledge Cora Olgyay, daughter of Victor Olgyay, who lent us her personal collection of her father's papers and provided important background information on the Olgyay family. Her brother, Victor, searched the personal collection of photographs in the possession of their mother, Ilona Olgyay, in order to provide the photograph of the twins in [1]. James Robert Allen, Library Supervisor, Arizona State University, provided invaluable support in our research of the Victor Olgyay Collection, 1852-1970 in the Architectural and Environmental Design Library, Arizona State University. We thank Gabrielle Ruddick, a Ph.D. candidate at the University of Pennsylvania, for carefully proofreading this paper and for her assistance in obtaining copyright permissions.

\section{Illustration credits}

arq gratefully acknowledges:

Domus, 2

Fondation Le Corbusier, 5

Cora and Victor Olgyay, 1

Princeton University Press, 7, 8

US Government Printing Office, 3 ,

$$
4,6
$$

\section{Authors' biographies}

David Leatherbarrow is Professor of Architecture at the University of Pennsylvania where he teaches design, history and theory. He is chair of Penn's Graduate Group in Architecture and supervises Ph.D. research. He is author of Architecture Oriented Otherwise, Surface Architecture (with Mohsen Mostafavi) and Topographical Stories.

Richard Wesley is adjunct Professor of Architecture and undergraduate chair at the University of Pennsylvania where he teaches undergraduate design and theory. He has taught at the University of Illinois, University of Notre Dame, and Harvard University and has published essays in Harvard Architecture Review, Rassegna, Res and VIA.

\section{Authors' addresses}

David Leatherbarrow

leatherb@design.upenn.edu

Richard Wesley

rwesley@design.upenn.edu 